\title{
Acute systemic response to intraperitoneal implantation of polypropylene mesh/chitosan- based film composite in pigs ${ }^{1}$
}

\author{
Apóstolo Ferreira Martins', Naida Cristina Borges", Priscila Vaz Coutinho"II, Aline Rodrigues Lemes ${ }^{\text {III }}$, Ashbel Schneider da \\ Silva $^{\text {IV }}$, Rayssa Kossa Barbosa ${ }^{\mathrm{III}}$, Neusa Margarida Paulov \\ DOI: http://dx.doi.org/10.1590/S0102-865020150100000004 \\ ${ }^{1}$ Fellow Master degree, Postgraduate Program in Animal Science, School of Veterinary Medicine and Zootechny, Universidade Federal de Goiás \\ (UFG), Goiania-GO, Brazil. Intellectual and scientific content of the study, acquisition and interpretation of data, surgical procedures. \\ "PhD, Full Professor, School of Veterinary Medicine and Zootechny, UFG, Goiania-GO, Brazil. Intellectual and scientific content of the study. \\ IIIGraduate student, School of Veterinary Medicine and Zootecny, UFG, Goiania-GO, Brazil. Technical procedures.

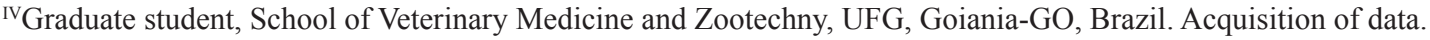 \\ ${ }^{v} \mathrm{PhD}$, Full Professor, School of Veterinary Medicine and Zootechiny, UFG, Goiania-GO, Brazil. Conception, design, intellectual and scientific content \\ of the study.
}

\section{ABSTRACT}

PURPOSE: To assess the systemic response of pigs to the intraperitoneal implantation of polypropylene mesh associated with chitosanbased film with a degree of deacetylation of $95 \%$.

METHODS: Blood samples were collected 24 hours before, and two and seven days after surgery. Systemic reactions were evaluated based on white blood cell count, C-reactive protein, and total serum protein, albumin and globulin levels.

RESULTS: The systemic response was proportional to the composite response induced by polypropylene mesh, and the tissue inflammatory response was higher in the PP group $(\mathrm{p}=0.0033)$.

CONCLUSION: The polypropylene mesh/chitosan-based film composite did not elicit a systemic response in pigs.

Key words: Chitosan. Peritoneum. Surgical Mesh. Swine. 


\section{Introduction}

When a tissue is injured or attacked through trauma or infections, it suffers systemic disorders that are characterized by leukocytosis, increased capillary permeability, increased blood protein levels produced by the liver, changes in steroid concentrations and minerals, as well as fever ${ }^{1}$. These changes, known as systemic response, correspond to an inflammatory response usually induced by a group of proteins called cytokines ${ }^{2}$.

The production of biocompatible prosthetic materials has contributed to increase their use for the repair of abdominal wall defects. Laboratory assessments of inflammatory response to surgical trauma objectively determine the magnitude of stress caused by surgical procedures.

The tissue recovery process is triggered by the following chemical mediators of acute inflammation: interleukin 8 (IL-8), monocyte chemoattractant protein-1 (MCP-1), TNF- $\alpha$, IL-1 $\beta$ and IL- 6 cytokines, transforming growth factor beta (TGF- $\beta$ ), a growth factor similar to insulin-like growth factor-1 (IGF-1), and platelet-derived growth factor (PDGF) $)^{3,4}$.

Growth factors, together with cytokines, induce the liver to produce increasing concentrations of proteins in the bloodstream, known as positive acute-phase proteins ${ }^{5}$. C-reactive protein (CRP) is usually augmented during the course of an inflammatory process. Like an acute-phase protein primarily synthesized in the liver, it is stored in the endoplasmic reticulum of the hepatocytes. When the synthesis of this protein is stimulated, its bond to the endoplasmic reticulum decreases, thereby increasing its presence in the bloodstream ${ }^{6}$.

CRP interacts with phagocytic cell receptors to mediate phagocytosis and induce anti-inflammatory cytokine production, and inhibit polymorphonuclear cell chemotaxis ${ }^{7}$. After trauma, these cells are the first to appear at the site of the lesion, where they remain at high levels for one to two days. The migration of monocytes through the mesothelial monolayer to the site of the lesion occurs more gradually,8.

Bioactive agents have been proposed to protect meshes used in abdominal wall reconstruction surgery against the defenses of the innate immune system, modulate local fibrosis in patients with deficient extracellular matrix synthesis, and prevent infections after implantation of the biomaterial. Natural polymers such as chitosan are studied for this purpose. They are macromolecules considered immunogenic, which can be recognized and metabolized by the host ${ }^{9}$.

The measurement of CRP levels is considered an important test in the assessment of systemic inflammatory responses, and also as an inflammatory biomarker in pigs ${ }^{7,10}$.

When a prosthesis is implanted in the abdominal wall, it usually elicits a predictable inflammatory reaction that evolves to fibrosis and culminates in its incorporation into the subjacent tissues. The prosthetic implant therefore provides mechanical support to the wall and enables the formation of a neoperitoneum over the material ${ }^{11}$.

To minimize or prevent the formation of intraperitoneal adhesions on implanted polypropylene meshes, one of the sides of the mesh can be coated with a product between it and the visceral peritoneum. These materials, consisting of a combination of the mesh with another biopolymer, are known as composites. The additional layer will thus act as a barrier system, combining the toughness of the mesh with the anti-adhesive action of the coating $^{11,12}$.

Chitin and chitosan have been studied extensively in Asia since the 1960s. The main objective of such studies is to learn more about the methods of production, purification, derivative chemistry and applications of these fibers ${ }^{13}$. Chitosan, by definition, is an N-deacetylated mucopolysaccharide derived from chitin. It is considered a natural fiber with a high potential for biomedical use because of its biocompatibility, biodegradability and non-toxicity, unlike synthetic polymers, which have limited properties. This explains the significance of the research into this biomaterial $^{14,15}$.

The aim of this study was to compare the acute systemic response elicited by a polypropylene mesh implant coated with chitosan-based film against that elicited by uncoated polypropylene mesh employed in the correction of experimental abdominal wall defects in pigs.

\section{Methods}

This study was approved by the Research Ethics Committee of the Universidade Federal de Goiás - UFG (Protocol no. 208/2011).

Twelve healthy hybrid male pigs were used, with an average weight of $16.25 \mathrm{~kg} \pm 2.34 \mathrm{~kg}$, supplied by the swine raising department of the Federal University of Goiás School of Veterinary Medicine and Animal Science. The animals were housed in individual pens, where they remained for a 7-day period of adjustment and clinical monitoring.

To evaluate acute systemic response to the implantation of polypropylene mesh/chitosan-based film_composite, the pigs were randomly divided into two groups of six animals each. The 
group intraperitoneally implanted with polypropylene mesh was dubbed PP, and the group implanted with the chitosan membrane/ polypropylene mesh_composite was dubbed PQ.

The surgical polypropylene mesh, $0.45 \mathrm{~mm}$ thick and with $0.5 \mathrm{~mm}^{2}$ size pores, was cut into $4 \times 4 \mathrm{~cm}$ squares (Figure 1A). Composites of the same size were prepared from the same polypropylene mesh, with one side coated with a thick film of chitosan with a degree of deacetylation of $95 \%$ (Figure 1B) by means of the immersion technique. The composites were developed in the Laboratory of Bioreaction and Colloid Engineering of the School of Chemical Engineering at the State University of Campinas - UNICAMP, São Paulo. The composite was sterilized by exposure to ethylene oxide.
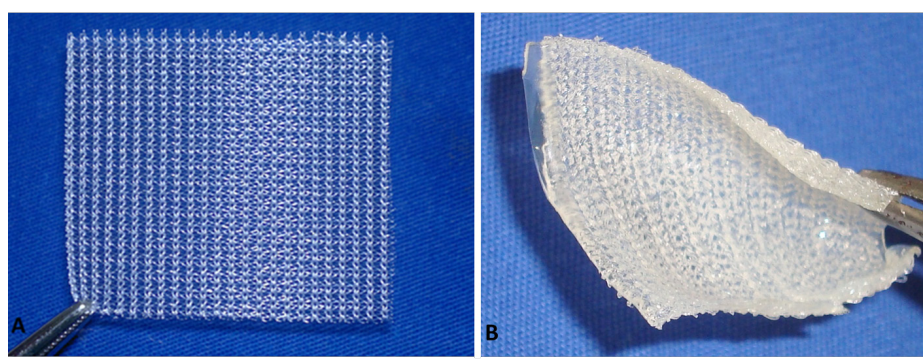

FIGURE 1 - (A) Surgical polypropylene mesh. (B) Polypropylene mesh coated with chitosan-based film.

Prior to implantation in the abdominal wall, the polypropylene meshes were immersed in Ringer's solution for thirty minutes.

The animals were sedated with a single intramuscular dose of ketamine (10 mg/kg), azaperone ( $3 \mathrm{mg} / \mathrm{kg})$ and midazolam $(0.5 \mathrm{mg} / \mathrm{kg})$. Deep anesthesia was then induced with propofol (3 $\mathrm{mg} / \mathrm{kg}$ ) and maintained with isoflurane in a diluent oxygen flow of $30 \mathrm{ml} / \mathrm{kg} / \mathrm{min}$.

An approximately 6-cm transverse right side paramedian incision was made close to the umbilicus. After exposing the transverse abdominal muscle, a longitudinal fragment of this muscle was excised to create a defect in the abdominal wall. The meshes were fixed to the edges of the defect with a simple continuous suture. In the PQ group, the chitosan-coated side of the mesh faced towards the peritoneal cavity. The muscle planes and subcutaneous tissue were reconstructed with simple continuous sutures. All the repairs were performed using 2-0 polypropylene monofilament sutures (Figure 2).

Postoperative analgesia was provided by intramuscular administration of tramadol $(2.0 \mathrm{mg} / \mathrm{kg})$ every eight hours, in the first 24 hours, followed by dipyrone $(25 \mathrm{mg} / \mathrm{kg}$ ) every 12 hours for five days. Antibiotic therapy consisted of three doses of $20.000 \mathrm{IU}$ of benzathine benzylpenicillin $/ \mathrm{kg}$ at 48 hour intervals. The surgical wound was cleaned daily with $0.9 \%$ saline and disinfected with topical povidone-iodine solution until it was completely healed.

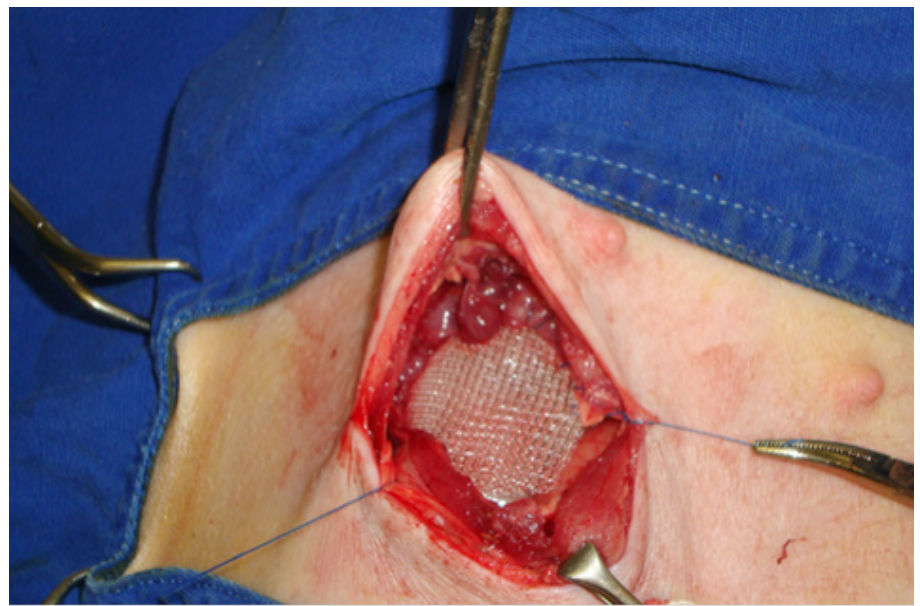

FIGURE 2 - Surgical polypropylene mesh intraperitoneally implanted to correct the defect experimentally induced in the abdominal wall of a pig.

Pre and postoperative laboratory parameters were measured in three stages: 24 hours before (moment zero $-M_{0}$ ), two days after (moment one $-\mathrm{M}_{2}$ ) and seven days after surgery (moment two $-\mathrm{M}_{7}$ ). Blood drawn from the external jugular vein was used in these exams. For the white blood cell count (WBC), $3 \mathrm{ml}$ of blood were processed in a veterinary hematology autoanalyzer. A differential leukocyte count was also made using blood smears processed with rapid stain. For biochemical analysis, $4 \mathrm{ml}$ of serum was obtained by centrifuging blood collected without anticoagulant.

Total serum protein and albumin were measured by endpoint colorimetric methods, using the Biuret reaction and bromocresol green in acidic medium, respectively. C-reactive protein was determined by the turbidimetric method (PCR). The biochemical analyses were performed in a semi-automated biochemistry analyzer. All the samples were processed and analyzed on the day they were collected. The baseline values obtained at $M_{0}$ were used as reference for comparison of the laboratory results of all the animals.

The data were analyzed with free $\mathrm{R}$ software ( $\mathrm{R}$ Core Team, 2013), applying ANOVA, followed by multiple comparison 
tests, with $P$ values considered significant when $p<0.05$. The values $\mathrm{p}_{1}$ indicate comparisons between treatments, while the $\mathrm{p}_{2}$ values represent comparisons between moments.

\section{Results}

Postoperative seroma was observed in the first 15 days in $33.33 \%$ of the animals of group PP and in $16.67 \%$ of the animals of group PQ. Superficial wound infection occurred in two animals $(33.33 \%)$ of group PP and in three animals (50\%) of group PQ.
There was no significant difference between groups PP and PQ in terms of total counts of WBC, rods, neutrophils, eosinophils, lymphocytes and monocytes $\left(\mathrm{p}_{1}>0.05\right)$, except for monocytes, which varied between moments $\left(\mathrm{p}_{2}<0.05\right)$, as shown in Table 1.

CRT, serum protein, albumin and globulin levels measured two and seven days after implantation showed no significant variations between the groups $\left(\mathrm{p}_{l}>0.05\right)$. However, total serum protein and albumin levels showed significant differences between moments $\left(\mathrm{p}_{2}<0.05\right)$, as indicated in Table 2 .

TABLE 1 - Average blood cell counts evaluated in groups PP and PQ 24 hours before surgery $\left(\mathrm{M}_{0}\right)$, and two and seven days after surgery $\left(\mathrm{M}_{2}, \mathrm{M}_{7}\right)$

\begin{tabular}{|c|c|c|c|c|c|}
\hline \multicolumn{6}{|c|}{ Groups } \\
\hline $\begin{array}{c}\text { Variable } \\
\left(\mathrm{mm}^{3}\right)\end{array}$ & Moment & PP & PQ & $\mathrm{p}_{1}$ & $\mathrm{p}_{2}$ \\
\hline \multirow{3}{*}{ WBC } & $\mathrm{M}_{0}$ & $11350 \pm 4410$ & $8800 \pm 4036$ & \multirow{3}{*}{0.2655} & \multirow{3}{*}{0.0610} \\
\hline & $\mathrm{M}_{2}$ & $14567 \pm 4852$ & $11117 \pm 1685$ & & \\
\hline & $\mathrm{M}_{7}$ & $12267 \pm 3934$ & $12433 \pm 1925$ & & \\
\hline \multirow{3}{*}{ Rods } & $\mathrm{M}_{0}$ & $386 \pm 300$ & $376 \pm 234$ & \multirow{3}{*}{0.5394} & \multirow{3}{*}{0.7663} \\
\hline & $\mathrm{M}_{2}$ & $510 \pm 366$ & $264 \pm 184$ & & \\
\hline & $\mathrm{M}_{7}$ & $271 \pm 216$ & $365 \pm 167$ & & \\
\hline \multirow{3}{*}{ Neutrophils } & $\mathrm{M}_{0}$ & $3500 \pm 1795$ & $3112 \pm 2845$ & \multirow{3}{*}{0.6769} & \multirow{3}{*}{0.0529} \\
\hline & $\mathrm{M}_{2}$ & $5086 \pm 3307$ & $4256 \pm 1476$ & & \\
\hline & $\mathrm{M}_{7}$ & $5598 \pm 4501$ & $5094 \pm 1631$ & & \\
\hline \multirow{3}{*}{ Eosinophils } & $\mathrm{M}_{0}$ & $120 \pm 156$ & $105 \pm 95$ & \multirow{3}{*}{0.3341} & \multirow{3}{*}{0.0700} \\
\hline & $\mathrm{M}_{2}$ & $247 \pm 182$ & $257 \pm 188$ & & \\
\hline & $\mathrm{M}_{7}$ & $198 \pm 129$ & $319 \pm 122$ & & \\
\hline \multirow{3}{*}{ Lymphocytes } & $\mathrm{M}_{0}$ & $6799 \pm 3100$ & $4952 \pm 985$ & \multirow{3}{*}{0.0784} & \multirow{3}{*}{0.2246} \\
\hline & $\mathrm{M}_{2}$ & $8033 \pm 1829$ & $5756 \pm 845$ & & \\
\hline & $\mathrm{M}_{7}$ & $5612 \pm 1049$ & $6044 \pm 1473$ & & \\
\hline \multirow{3}{*}{ Monocytes } & $\mathrm{M}_{0}$ & $542 \pm 212^{\mathrm{a}}$ & $253 \pm 244^{a}$ & \multirow{3}{*}{0.4014} & \multirow{3}{*}{$0.0214^{*}$} \\
\hline & $\mathrm{M}_{2}$ & $690 \pm 351^{b}$ & $583 \pm 297^{\mathrm{b}}$ & & \\
\hline & $\mathrm{M}_{7}$ & $587 \pm 378^{b}$ & $610 \pm 260^{b}$ & & \\
\hline
\end{tabular}

${ }^{*} \mathrm{p}<0.05$ - Statistically significant. $\mathrm{p}_{1}$ values indicate comparisons between treatments, and $\mathrm{p}_{2}$ values indicate comparisons between moments. 
TABLE 2 - Average blood protein levels evaluated in groups PP and PQ 24 hours before surgery $\left(\mathrm{M}_{0}\right)$, and two and seven days after surgery $\left(\mathrm{M}_{2}, \mathrm{M}_{7}\right)$

\begin{tabular}{|c|c|c|c|c|c|c|}
\hline \multicolumn{7}{|c|}{ Groups } \\
\hline Variable & Moments & PP & PQ & & & $\mathrm{p}_{2}$ \\
\hline \multirow{2}{*}{$\begin{array}{l}\text { C-reactive } \\
\text { Protein } \\
\text { mg/L }\end{array}$} & $\mathrm{M}_{0}$ & $2.30 \pm 0.52$ & $1.34 \pm 0.54$ & \multirow{2}{*}{0.5392} & \multirow{2}{*}{0.2071} & \\
\hline & $\mathrm{M}_{7}$ & $1.48 \pm 1.04$ & $1.56 \pm 0.41$ & & & \\
\hline \multirow{2}{*}{$\begin{array}{c}\text { Serum Proteins } \\
\text { g/dL }\end{array}$} & $\mathrm{M}_{2}$ & $4.86 \pm 0.48^{\mathrm{b}}$ & $5.12 \pm 0.34^{\mathrm{b}}$ & \multirow[t]{2}{*}{0.8340} & \multirow[t]{2}{*}{$0.0483^{*}$} & \\
\hline & $\mathrm{M}_{7}$ & $5.59 \pm 0.45^{\mathrm{b}}$ & $5.33 \pm 0.67^{\mathrm{b}}$ & & & \\
\hline \multirow{2}{*}{$\begin{array}{l}\text { Albumin } \\
\mathrm{g} / \mathrm{dL}\end{array}$} & $\mathrm{M}_{0}$ & $3.55 \pm 0.41^{\mathrm{a}}$ & $3.70 \pm 0.49^{\mathrm{a}}$ & \multirow[b]{2}{*}{0.4283} & \multirow[b]{2}{*}{$0.0013 *$} & \\
\hline & $\mathrm{M}_{2}$ & $3.26 \pm 0.39^{b}$ & $3.70 \pm 0.49^{b}$ & & & \\
\hline \multirow{3}{*}{$\begin{array}{l}\text { Globulins } \\
\text { g/dL }\end{array}$} & $\mathrm{M}_{0}$ & $1.38 \pm 0.71$ & $1.27 \pm 0.55$ & \multirow{3}{*}{0.4268} & \multirow{3}{*}{0.1819} & \\
\hline & $\mathrm{M}_{2}$ & $1.61 \pm 0.76$ & $1.42 \pm 0.71$ & & & \\
\hline & $\mathrm{M}_{7}$ & $1.82 \pm 0.25$ & $1.43 \pm 0.16$ & & & \\
\hline
\end{tabular}

${ }^{*} \mathrm{p}<0.05$ - Statistically significant. $\mathrm{p}_{1}$ values indicate comparisons between treatments, and $\mathrm{p}_{2}$ values indicate comparisons between moments.

\section{Discussion}

Local inflammatory reaction to the biomaterial may have been responsible for the seroma observed in the region of the implant in the two animals of group PP and in one animal of group PQ in the initial postoperative days. This is a common occurrence that often requires no intervention, which usually takes 15 days to clear up, as has been reported in cattle, horses and goats, respectively, after the repair of abdominal wall defects with polypropylene mesh ${ }^{16,17}$.

The evaluation of the biocompatibility of an implant designed by biomaterials engineering includes the determination of the host's systemic response to the components of the material, its tissue reaction, and the combination of the two. The duration and intensity of the reactions depend, among other factors, on the extent of the injury created during implantation and the chemical composition of the biomaterial, which affect the degree of the local inflammatory process.

Despite the occurrence of local inflammation, it was certainly not sufficiently intense to elicit a significant systemic response to the implanted biomaterial. Such a response, known as acute inflammatory response, was recognized by Gauldie et $a l .{ }^{1}$, but that was not the case in this study, in which the levels of
C-reactive protein, a substance that appears early in inflammatory processes, were not augmented at the evaluated moments. Our findings pertaining to systemic inflammatory reaction contradict those reported by Di Vita et al. ${ }^{18,}$ who reported that lower tension abdomen repair using screens may be associated with an increase in inflammatory mediators in the first 48 hours, probably caused by foreign body reaction.

It can be inferred that, in this study, the size of the defect created in relation to the size of the animals did not suffice to induce significant leukocytosis in either of the groups. Moreover, the screen size may have contributed to a proportionally lower systemic response ${ }^{18}$. The magnitude of the acute-phase inflammatory response is an important factor to assess the degree of surgical trauma ${ }^{2}$, and the increase in systemic inflammatory response markers is associated with invasive surgical procedures. Depending on the extent of the injury, this response will cause an increase in the number of WBC circulating in the bloodstream, but this is not always accompanied by infectious processes.

Although local inflammatory response was not evaluated, the significant increase in circulating monocytes observed in both groups at $M_{2}$ and $M_{7}$ is a strong indicator of chronification of the inflammatory process triggered by the biomaterial implant. This finding is similar to that reported by other authors ${ }^{3,8}$, who noted that 
these cells were augmented up to day seven after peritoneal repair. The activation of macrophages at the implant site, in conjunction with the proliferation of fibroblasts, mark the onset of the chronic inflammation process required to trigger the mechanism of biomaterial incorporation.

The $1.2 \mathrm{~mm}$ thickness of the chitosan-based film applied as coating on the polypropylene mesh was expected to induce a stronger systemic immune response in the PQ group, as pointed out $^{9}$. The physical and chemical properties of biomaterials, and their surface topography and shape, are important in determining the type, intensity and duration of the inflammatory response. However, this event was not observed in this study, as demonstrated by the results of the comparison of the WBC and CRP levels between the groups.

The significant decrease expected in albumin ${ }^{5,7}$ levels reflected an adequate response of the animals. Acute-phase proteins may increase or decrease in response to changes in homeostasis. Pro-inflammatory agents are released by macrophages and other cells in response to various external and internal stimuli. These stimuli mobilize the hepatocytes to initiate the synthesis of positive acute-phase proteins. Concomitantly, there is a reduction in the synthesis of negative acute-phase proteins such as albumin, which is the most abundant component of plasma protein.

\section{Conclusion}

The systemic response to the polypropylene mesh/ chitosan-based composite was similar to that induced by the uncoated high-density polypropylene mesh, confirming the systemic biocompatibility of chitosan in pigs.

\section{References}

1. Gauldie J, Richards C, Harnish D, Lansdorp P, Baumann H. Interferon $\beta 2 / \mathrm{B}$-cell stimulatory factor type 2 shares identity with monocyte-derived hepatocyte-stimulating factor and regulates the major acute phase protein response in liver cells. Proc Natl Acad Sci. U.S.A.1987;84:7251-55. PMID: 2444978.

2. Gurleyik E, Gurleyik G, Cetinkaya F, Unalmiser S. The Inflammatory response to open tension free inguinal hernioplasty versus conventional repairs. Am J Surg.1998;175:179-82. doi: 10.1016/S0002-9610(97)00293-6.

3. Dizerega GS. Biochemical events in peritoneal tissue repair. Eur J Surg.1997;577:10-6. PMID: 9076447.

4. van Der Walt JBC, Jeekel J. Biology of the peritoneum in normal homeostasis and after surgical trauma. Colorectal Dis. 2007;9(2):913. PMID: 17824965.

5. Petersen HH, Nielsen JP, Heegaard PMH. Application of acute phase protein measurements in veterinary clinical chemistry. Vet Res. 2004;35:163-87. PMID: 15099494.

6. Du Clos TW, Mold C. C-Reactive protein. Immunol Res.
2004;30(3):261-77.

7. Murata H, Shimada N, Yoshioka M. Current research on acute phase proteins in veterinary diagnosis: an overview. Vet J. 2004;168:2840. doi: 10.1385/IR:30:3:261.

8. Cheong YC, Laird SM, Li TC, Shelton JB, Ledger W, Cooke ID. Peritoneal healing and adhesion formation/reformation. Hum Reprod Update. 2001;7:556-66. doi: 10.1093/humupd/7.6.556.

9. Lan C, Niu GC, Chang SJ, Yao C, Kuo SM. Chitosa in applications of biomedical devices. Biomed Eng Appl Basis Commun. 2011;23(1):51-62. doi: 10.4015/S1016237211002372.

10. Junge K, Binnebösel M, Trotha KTV, Rosch R, Klinge U, Neumann UP, Jansen PL. Mesh biocompatibility: effects of cellular inflammation and tissue remodeling. Langenbeck's Arch Surg. 2012;397:255-70. doi: 10.1007/ss443-011-0780-0.

11. Eckersall PD, Bell R. Acute phase proteins: biomarkers of infection and inflammation in veterinary medicine. Vet J. 2010;185:23-7. doi: 10.1016/j.tvj1.2010.04.009.

12. Bellón JM, García-Carranza A, Jurado F, García-Honduvilla N, Martin AC, Buján J. Peritoneal Regeneration after Implant of a Composite Prosthesis in the Abdominal Wall. World J Surg. 2001;25:147-52. doi: 10.1007/s0026800200069.

13. Zhou XL, Chen SW, Liao GD, Shen ZJ, Zhang ZL, Sun L, Yu YJ, $\mathrm{Hu}$ QL, Jin XD. Preventive effect of gelatinizedly-modified chitosan film on peritoneal adhesion of different types. World J Gastroenterol. 2007;13(8):1262-7. doi: 10.3748/wjg.v13.i8.1262.

14. Khor E, Lim LY. Implantable applications of chitin and chitosan. Biomaterials. 2003;24:2339-49. doi: 10.1016/S01429612(03)00026-7.

15. Kumar MNVR. A review of chitin and chitosan applications. Reactive Funct Polymers. 2000;46:1-27. doi: 10.1016/s13815148(00)00038-9.

16. Vilar JM, Doreste F, Spinella G, Valentini S. Double-layer mesh hernioplasty for repair of incisional hernias in 15 horses. J Equine Vet Sci. 2009;29(3):172-6. doi: 10.1016/j.jevs.2009.02.001.

17. Vilar JM, Corbera JA, Spinella G. Double-layer mesh hernioplasty for repairing umbilical hernias in 10 goats. Turk J Vet Anim Sci. 2011;5(2):131-5. doi: 10.3906/vet-1006-365.

18. Di Vita G, Milano S, Frazzetta M, Patti R, Palazzolo V, Barbera C, Ferlazzo V, Leo P, Cillari E. Tension-free hernia repair is associated with an increase in inflammatory response markers against the mesh. Am J Surg. 2000;180:203-7. doi: 10.1016/5002-9610(00)00445-1.

\section{Correspondence:}

Neusa Margarida Paulo

Universidade Federal de Goiás - Escola de Veterinária e Zootecnia (UFG/ EVZ)

Campus 2, Samambaia

74001-970 Goiânia - GO Brasil

nmp@ufg.br

Received: Jun 23, 2015

Review: Aug 26, 2015

Accepted: Sep 19, 2015

Conflict of interest: none

Financial source: FUNAPE

${ }^{1}$ Research performed at Experimental Surgery Laboratory, Department of Veterinary Medicine, School of Veterinary Medicine and Zootechny, Universidade Federal de Goiás (UFG), Goiania-GO, Brazil. 